\title{
Intergenerational Transmission of Political Party Preference in The Netherlands
}

\author{
Paul Nieuwberkta
}

Department of Sociology, University of Nijmegen, The Netheriands

AND

\section{KARIN WITTEBROOD}

\author{
Department of Political Science, University of Nijmegen, The Netherlands
}

This article examines the intergenerational transmission of political party preference by analyzing data from a national representative survey of high school students in the Netherlands in $1991(N=5,148)$. Multinominal logistic diagonal reference models are applied to analyze the data. In general, no difference is found between the relative influence of father's and mother's political party preference. However, father's party preference has more of an effect on son's party preference than mother's, while mother's party preference has more impact on daughter's party preference than father's. Finally, contrary to our hypothesis, the chance of children with politically heterogeneous parents having a political party preference is no less than that of children of politically homogeneous parents. C) 1595 Acadenic Press. Inc.

Intergenerational transmission of political party preference has frequently been studied in a number of different countries (Hyman, 1959; Campbell, Converse, Miller, and Stokes, 1960; Butler and Stokes, 1969; Jennings and Niemi, 1974, 1981; Himmelweit, Humphreys, Jaeger, and Katz, 1981; Converse and Pierce, 1986; Flanagan, Kohei, Miyake, Rich

This research was financially supported by the Netherlands Organization for Scientific Research (NWO Grants 500-179-001 and 430-224-001). The authors express their appreciation to Ad van Deemen, Jan van Deth, Gary King, Nan Dirk de Graaf, Kent Jennings, Ariana Need, Wout Ultee, Wilfred Uunk, the members of the department of Institutionen und sozialer Wandel at the Wissenschaftscentrum in Berlin, and two anonymous reviewers for their useful comments on earlier drafts of this article. We especially thank Richard Breen for showing us how to estimate the parameters of multinominal logistic diagonal reference models. Address correspondence and reprint requests to Paul Nieuwbeerta, Utrecht University, Department of Sociology, Heidelberglaan 1, 3584 CS Utrecht, The Netherlands. 
ardson, and Watanuki, 1991; Wittebrood, 1993a). Without exception, these studies revealed high similarity between parents' and children's political party preferences, indicating a strong intergenerational transmission of political party preference.

However, the extent of similarity differs between children whose parents prefer the same political party (politically homogeneous parents) and children whose parents prefer different political parties (politically heterogeneous parents) (Jennings and Niemi, 1974; Niemi, Newman, and Weimer, 1982). Where both parents prefer the same political party, their child is influenced in the same direction. Consequently, it can be assumed that this child will adopt its parents' political preference. A child with politically heterogeneous parents is torn between father's and mother's political party preferences. The child is exposed to opposite influences which create uncertainty and ambiguity regarding an appropriate political response. The extent of similarity between the political party preference of the child with that of the parents can be expected to be less than that of a child with politically homogeneous parents.

The central question addressed in this article concerns the influence of fathers and mothers on the political party preference of their children in the Netherlands. The existing political socialization literature pays very little attention to the intergenerational transmission of political party preference in the Netherlands. Questions regarding this topic have been posed only incidentally in Dutch youth and electoral research (Hagendoorn and Janssen, 1983; Janssen and Voestermans, 1984; De Hart, 1990).

According to Jennings, Allerbeck, and Rosenmayr (1979); Jennings (1984); and Westholm and Niemi (1992), political socialization processes in the Netherlands differ from those in other countries. This is reffected in the lowest parent-offspring similarity of partisanship of all countries where research on this subject has been carried out. Parent-offspring similarity is somewhat lower than in West Germany, Italy, United States, and Switzerland and much lower than in Austria, United Kingdom, Finland, and Sweden. Two explanations are offered. First, in countries with a multiparty political system such as the Netherlands, intergenerational transmission of political party preference is less powerful than in twoparty political systems (Percheron and Jennings, 1981). Second, as Thomassen (1976) showed, individual political party preference in The Netherlands is not based on a stable party identification, causing a lower rate of transmission than in countries where party identification plays a major role (Westholm and Niemi, 1992).

In order to investigate intergenerational transmission of political party preference in the Netherlands, we formulated explicit hypotheses based on earlier political socialization studies done mostly in other countries. We tested our hypotheses by analyzing data from a survey held among high school pupils in the Netherlands in 1991. 


\section{HYPOTHESES}

It is assumed that both the father and the mother influence their child's political party preference. If the parents prefer the same political party, the child is doubly influenced in the same direction. In this situation, knowing which parent is the more influential is of little relevance. A child with politically heterogeneous parents is exposed to counteractive influences. In order to explain political party preference of such child, it is important to find out whether there is a difference between the effect of the father's and the mother's political preference. In this article, we state a number of hypotheses on the relative influence of parents' political party preference on that of their child. As a baseline we formulate the equalparental socialization hypothesis: Mother's and father's political party preferences are equally influential on a child's political party preference.

The first studies done on voting behavior assumed that the father's political role was dominant in political socialization processes (see for example Lazarsfeld, Berelson, and Gaudet, 1948). The father was assumed to be the more dominant socialization agent in the intergenerational transmission of political party preference. However, empirical research in various western countries has never corroborated this idea. Many studies found the mother to be the more dominant socialization agent (Jennings and Niemi, 1971, 1974). A possible explanation for this is that, in general, mothers spend more time with their children in their formative years than fathers. As a result, children develop closer affective ties with their mother than with their father (Asher, 1980; Himmelweit et al., 1981). We postulate the mother-dominated socialization hypothesis: The mother's political party preference influences a child's political party preference more than the father's.

A related question is whether the impact of the political party preference of fathers and mothers is equal for sons and daughters. Since children identify more with the same-sex parent, earlier studies expected sons to be relatively more influenced by their fathers and daughters by their mothers (Maccoby and Jacklin, 1974). Most political socialization studies on gender-specific socialization confirm this idea (Jennings and Niemi, 1974; Niemi, Ross, and Alexander, 1978; De Hart, 1990). We therefore refined our mother-dominated socialization hypothesis to include the assumption that the influence of father's and mother's political party preference depends on the sex of their child. The result is two gender-specific socialization hypotheses: (a) The mother's political party preference influences a daughter's political party preference more than the father's, and (b) The father's political party preference influences a son's political party preference more than the mother's.

These hypotheses concern the effects of the father's and mother's political party preference on that of their child. It is assumed that, regardless 
of the effects of the father's and mother's political party preference, the exposure of a child with politically heterogeneous parents to cross-pressures has an effect in itself. In their well-known study, Lazarsfeld et al. (1948) showed that voters exposed to cross-pressures have less chance of having a political preference than voters not exposed to cross-pressures. A child influenced by the parents in different political directions will therefore to be less apt to have a political party preference. Cross-pressures create uncertainty and ambiguity as to an appropriate political response. The child will react to this uncertainty by not having a political party preference at all, thus avoiding political conflict with the parents. This leads to the following heterogeneity hypothesis: $A$ child with politically heterogeneous parents is less apt to prefer a political party than a child with politically homogeneous parents.

Referring to the study of Lazersfeld et al. (1948), Sperlich argued that it is not just the cross-pressure situation per se, but the magnitude of cross-pressure that is relevant in explaining political behavior (1971, p. 28 ). This implies that the more the parents differ in political party preference, the less chance there is that their child will have a political party preference. Therefore, a magnitude of heterogeneity hypothesis can be formulated: The more heterogeneous the political party preference of parents, the less apt their child is to have a political party preference.

\section{DATA}

The hypotheses were tested with data from a study on the acquisition and development of political involvement of adolescents in The Netherlands. Data were collected from 10,248 pupils at 71 randomly selected high schools (in senior general secondary education (havo) and pre-university education (vwo)) in 1991. Pupils in the $15-17$ age group filled in a paper-and-pencil questionnaire. Thirty-seven percent provided no information on their parents' political party preferences. ${ }^{1}$ In addition, 9\% of the pupils did not answer questions on relevant characteristics used for control, such as gender, social class, and religion. As a result, analysis was restricted to 5148 pupils. The final selection of pupils was not based on the dependent variable, the children's political party preference. It is therefore unlikely that this restricted selection influences the results of the study. ${ }^{2}$

\footnotetext{
1 This finding is confirmed by other surveys among adolescents in the Netherlands. In a study done by Social and Cultural Planning office (SCP, 1994), for example, it is found that about $40 \%$ of children are not acquainted with the party preference of their parents.

2 In a separate analysis we examined the nature of a possible bias in the selection of the children (Wittebrood, 1993b). The most relevant bias was an overrepresentation of children who were interested in politics. However, an additional analysis in which children who had indicated that they were not interested in politics were deleted (and thus the systematic bias was enlarged) lead to similar conclusions as the analysis discussed in this article.
} 
The main variables in our analysis are the political party preference of children and the political party preference of their parents. Children were asked which party they would vote for if there were general elections today and which party their parents would vote for. The six political parties in the questionnaire were the left-wing political parties, GL (Green Left), D66 (Democrats '66) and PvdA (Labor Party); the secular rightwing party, VVD (People's Party for Freedom and Democracy); and the denominational political parties, CDA (Christian Democratic Appeal) and SR (small right: a combination of three small protestant parties, GPV [Reformed Political Union], RPF [Reformed Political Federation], and SGP [Political Reformed Party]). There was also the option "no preference." This answer was used as our reference category, political preference being a nominal variable in our analysis.

The survey data do not contain information on the actual parental political preference, only on the parents' political preference as perceived by their children. According to Niemi (1974), this might lead to a small overestimation of the similarity between the parents' political party preference and that of their children. ${ }^{3}$ It also might lead to a small overestimation of the number of homogeneous parents in our data (Acock and Bengtson, 1980; Niemi, 1973, 1974). However, these shortcomings are believed to have no serious consequences for the conclusions presented in this article for two reasons. First, most hypotheses deal with relative influence of political party preference instead of absolute influence. Second, shortcomings in the data make the test of the heterogeneity hypotheses even stronger. It can be assumed that those children who perceive their parents to be politically heterogeneous will be more likely to experience cross-pressures and consequently will be more apt to prefer no political party at all, than children who do not realize that their parents are politically heterogeneous. Therefore, when we do not find an effect of heterogeneous parents it is extra unlikely that such effects occurred. Rejection of the hypotheses due to shortcomings in the data should be taken as a profound indication that these hypotheses do not hold.

To test the gender-specific socialization hypothesis, we include two additional variables in our models: girl, coded as ( 0 ) for boys and (1) for girls; and boy, coded as ( 0 ) for girls and (1) for boys.

To test our two heterogeneity hypotheses which state that there is an independent effect of politically heterogeneous parents on the political party preference of their children, we created two variables. The first variable is a dummy variable, heterogeneity, coded $(0)$ for children who

\footnotetext{
${ }^{3}$ Bengtson and Kuypers (1971) suggested a "development stake" hypothesis that states that children characteristically overestimate the amount of disagreement in opinions and values with their parents. In empirical analysis, however, this hypothesis has not been corroborated (Niemi, 1974).
} 
have politically hornogeneous parents and coded (1) for children who have politically heterogeneous parents. The second variable is the magnitude of heterogeneity. To construct this variable, many possible procedures could be used. We used one which first gives a score on a left-right scale to each political party based on the mean left-right placement of all children who preferred that party. These scores are Green Left (3.4), PvdA (4.4), D66 (4.8), CDA (5.8), VVD (6.8), and small right (7.3). Subsequently, the difference between the father's and mother's political party preference is calculated for each child. Children with politically homogeneous parents, consequently, score zero on this variable. ${ }^{4}$

Finally, we include variables referring to the child's socioeconomic class and religious denomination. Investigating the effects of direct political socialization, it is good practice to take into account indirect socialization through the child's reference groups (Flanagan, 1991, p. 150). Socioeconomic class is based on the highest class position of one of the parents. Three classes are distinguished, white-collar working class, blue-collar working class, and farmers. With regard to religion, two categories are distinguished, non-religious and religious. Because the influence of socioeconomic class differs in the Netherlands between religious and nonreligious people (Lijphart, 1975; Andeweg, 1982), dummy variables were included in our models for each of the class-religion combinations. Nonreligious blue-collar workers are taken as the reference category.

\section{POLITICAL PARTY PREFERENCE OF FATHERS, MOTHERS, AND THEIR CHILDREN}

Table 1 shows the political party preference of fathers, mothers, and their children. As might be expected in the Dutch situation in 1991, the Christian Democratic Appeal (CDA) has the highest percentage of adherents among children and parents, while the left-wing Green Left (GL) party and the denominational parties combined in small right (SR) have the lowest percentage. Furthermore, as the figures in Table 1 indicate, an average of $4 \%$ of the children show no political party preference.

Table 1 also shows the distribution of political party preferences of the various reference groups. There is a strong relation between religion and political preference. Of all non-religious children, only $15 \%$ stated a preference for one of the denominational political parties (CDA and small right), whereas $61 \%$ of the religious children preferred a denominational

\footnotetext{
4 To apply an interval variable as measure for the magnitude of heterogeneity seems contradictory to our recommendation of treating voting behavior as a nominal variable. Alternative strategies, such as using several dummy variables that represent distances between particular political party preferences of fathers and mothers, however, complicated our models substantially. Furthermore, such models did not yield different conclusions. For these reasons, we present only the results of the analysis using the interval variable as measure for the magnitude of heterogeneity.
} 
TABLE 1

Political Party Preference of Fathers, Mothers, and Children in the Netherlands in 1991 (Percentages; $N$ between Brackets)

\begin{tabular}{|c|c|c|c|c|c|c|c|c|c|}
\hline & \multicolumn{7}{|c|}{ Political party preference } & \multirow{2}{*}{\multicolumn{2}{|c|}{ Total }} \\
\hline & PvdA & CDA & VVD & D66 & $\begin{array}{c}\text { Green } \\
\text { left }\end{array}$ & $\begin{array}{l}\text { Small } \\
\text { right }\end{array}$ & $\begin{array}{c}\text { No } \\
\text { preference }\end{array}$ & & \\
\hline Fathers & 18 & 36 & 20 & 11 & 3 & 11 & - & 100 & (5148) \\
\hline Mothers & 17 & 36 & 16 & 14 & 6 & 12 & - & 100 & (5148) \\
\hline Children (ali) & 9 & 28 & 16 & 26 & 7 & 10 & 4 & 100 & $(5148)$ \\
\hline \multicolumn{10}{|l|}{ Children } \\
\hline $\begin{array}{l}\text { Religious, from non-manua! working } \\
\text { class background }\end{array}$ & 4 & 40 & 12 & 19 & 4 & 19 & 3 & 100 & (2048) \\
\hline Religious, from manual class background & 7 & 46 & 4 & 15 & 4 & 21 & 4 & 100 & $(400)$ \\
\hline Religious, from farmers background & 2 & 53 & 13 & 5 & 1 & 25 & 2 & 100 & (148) \\
\hline $\begin{array}{l}\text { Non-religious, from non-manual working } \\
\text { class background }\end{array}$ & 12 & 15 & 22 & 36 & 10 & 1 & 4 & 100 & (2227) \\
\hline $\begin{array}{l}\text { Non-religious, from manual working } \\
\text { class background }\end{array}$ & 31 & 14 & 8 & 28 & 13 & 1 & 5 & 100 & (286) \\
\hline Non-religious, from farmers background & 3 & 18 & 39 & 31 & 8 & - & 3 & 100 & (39) \\
\hline
\end{tabular}


party. Furthermore, within the religious and non-religious groups there were significant differences in political preferences between children with a blue-collar and a white-collar working class background. Of the nonreligious children from a blue-collar background, $31 \%$ preferred the Labor Party, while for non-religious children from a white-collar background this is $12 \%$. Although the importance of socioeconomic and religious cleavages has decreased in the Netherlands during the last decades, these findings illustrate that even among children they are still politically relevant (Van der Eijk and Niemöller, 1992; Nieuwbeerta and De Graaf, 1995).

The relationship between political party preference of children and that of their parents is shown in Table 2. The figures in the cells on the main diagonal of this table give the political party preferences of children with politically homogeneous parents. The results of $75 \%$ of the children are found in these cells. The upper left cell shows that children whose parents both prefer the PvdA have a $50 \%$ chance of preferring that party. It is not exceptional that children have the same political preference as their parents. The figures in the other cells on the main diagonal show that children with homogeneous CDA parents have a $70 \%$ chance of having the same political party preference as their parents, children of homogeneous VVD parents have a $70 \%$ chance, children of homogeneous D66parents have a $79 \%$ chance, children of homogeneous Green Left-parents have a $71 \%$ chance, and children with small right parents have a $90 \%$ chance. An average of $71 \%$ of the children with politically homogeneous parents have the same political preference as their parents.

The off-diagonal cells show the chance which a child with politically heterogeneous parents has for a particular political party preference. For these children, the chance of same political party preference as father or mother is less than that for children with politically homogeneous parents. For example, for the children whose fathers prefer the PvdA and whose mothers prefer the CDA, $19 \%$ had the same party preference as their father and $35 \%$ the same as their mother. For those children with politically heterogeneous parents, an average of $34 \%$ had the same political preference as their father and $38 \%$ the same as their mother. The figures in Table 2 show that children with politically heterogeneous parents have about the same chance of not preferring a political party as children with politically homogeneous parents, i.e. $4 \%$.

\section{MULTINOMINAL LOGISTIC DIAGONAL REFERENCE MODELS}

Research on intergenerational transmission of political party preference has been confronted with the problem of how the influence of fathers and mothers can be placed in a model (Niemi et al., 1982; Sorenson and Brownfield, 1991). Using classical techniques such as an ANOVA-like model, the problem of the high correlation between the father's and the mother's party preference arises. In this study, for example, $75 \%$ of all 
TABLE 2

Percentages of Children Who Prefer a Particular Party, Given Their Fathers' and Mothers' Political Party Preference in the Netherlands in 1991 ( $N$ between Brackets).

\begin{tabular}{|c|c|c|c|c|c|c|c|c|c|c|c|c|}
\hline \multirow{3}{*}{$\begin{array}{l}\text { Political party } \\
\text { preference: Father } \\
\text { PrdA }\end{array}$} & \multicolumn{12}{|c|}{ Political party preference: Mother } \\
\hline & \multicolumn{2}{|c|}{ PvdA } & \multicolumn{2}{|c|}{$\mathrm{CDA}$} & \multicolumn{2}{|c|}{ VVD } & \multicolumn{2}{|c|}{ D66 } & \multicolumn{2}{|c|}{ Green left } & \multicolumn{2}{|c|}{ Small right } \\
\hline & Prda: & 50 & PrdA: & 19 & PvdA: & 42 & PvdA: & 14 & PvdA: & 21 & PrdA: & 50 \\
\hline & CDA: & 5 & CDA: & 35 & CDA: & - & CDA: & 4 & CDA: & 1 & CDA: & - \\
\hline & VVD: & 4 & VVD: & 6 & VVD: & 25 & VVD: & 7 & VVD: & - & VVD: & - \\
\hline & D66: & 28 & D66: & 28 & D66: & 17 & D66: & 63 & D66: & 28 & D66: & - \\
\hline & GL: & 10 & GL: & 8 & GL: & 8 & GL: & 9 & GL: & 44 & GL: & - \\
\hline & sr: & 0 & sr: & - & sr: & - & sr: & - & sr: & - & sr: & 50 \\
\hline & np: & 3 & np: & 4 & np: & 8 & np: & 4 & np: & 6 & np: & - \\
\hline & \multicolumn{2}{|c|}{$(649)$} & \multicolumn{2}{|c|}{ (78) } & \multicolumn{2}{|c|}{ (12) } & \multicolumn{2}{|c|}{ (118) } & \multicolumn{2}{|c|}{ (89) } & \multicolumn{2}{|c|}{ (2) } \\
\hline \multirow{8}{*}{$\mathrm{CDA}$} & PydA: & 26 & PvdA: & 2 & PvdA: & - & PvdA: & 2 & PrdA: & 10 & PvdA: & - \\
\hline & CDA: & 18 & CDA: & 70 & CDA: & 40 & CDA: & 22 & CDA: & 29 & CDA: & 57 \\
\hline & VVD: & 7 & VVD: & 6 & VVD: & 35 & VVD: & 7 & VVD: & 3 & VVD: & 3 \\
\hline & D66: & 33 & D66: & 16 & D66: & 15 & D66: & 59 & D66: & 26 & D66: & 17 \\
\hline & GL: & 7 & GL: & 3 & GL: & 6 & GL: & 8 & GL: & 29 & GL: & 3 \\
\hline & sr: & - & st: & 0 & sr: & - & sr: & - & sr: & - & sr: & 10 \\
\hline & np: & 9 & np: & 4 & np: & 4 & np: & 3 & np: & 3 & nр: & 10 \\
\hline & \multicolumn{2}{|c|}{$(55)$} & \multicolumn{2}{|c|}{ (1516) } & \multicolumn{2}{|c|}{$(102)$} & \multicolumn{2}{|c|}{ (121) } & \multicolumn{2}{|c|}{ (31) } & \multicolumn{2}{|c|}{ (30) } \\
\hline
\end{tabular}

VVD

PvdA: 13 PvdA: 2 PvdA: 2 PvdA: - PvdA: - PvdA: CDA: 10 CDA: 36 CDA: 7 CDA: 5 CDA: 11 CDA: 40 VVD: 23 VVD: 41 VVD: 70 VVD: 30 VVD: 11 VVD: 20 D66: 35 D66: 16 D66: 14 D66: 60 D66: 53 D66: 40 GL: 10 GL: 1 GL: 2 GL: 4 GL: 21 GL: -

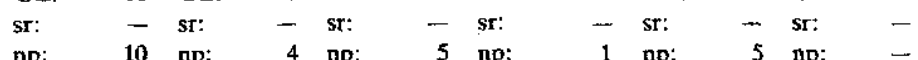
$\begin{array}{llllll}\text { (40) } & (195) & (651) & \text { (103) } & \text { (19) } & \text { (5) }\end{array}$

D66

PvdA: 19 PvdA: 7 PvdA: - PvdA: 1 PvdA: 6 PvdA: CDA: $\quad 3$ CDA: 28 CDA: 3 CDA: 6 CDA: 3 CDA: VVD: 6 VVD: 5 VVD: 35 VVD: 5 VVD: 6 VVD: 50 D66: 58 D66: 57 D66: 56 D66: 79 D66: 57 D66: 50

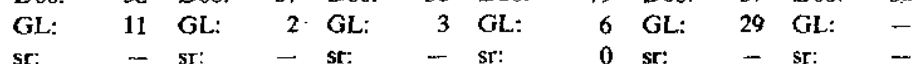

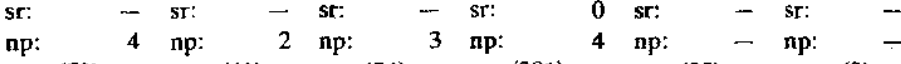

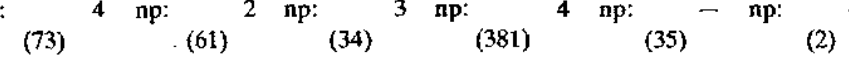

Green left PvdA: 10 PvdA: - PvdA: - PvdA: - PvdA: 3 PvdA: CDA: - CDA: - CDA: - CDA: - CDA: 2 CDA: VVD: - VVD: - VVD: - VVD: 6 VVD: 2 VVD: D66: 45 D66: 25 D66: 50 D66: 44 D66: 21 D66: GL: 42 GL: 75 GL: 50 GL: 50 GL: 71 GL: -

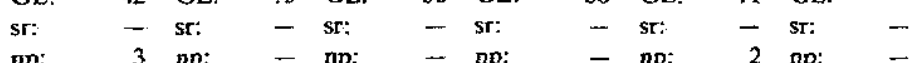
(31) (4) $\quad$ (4) $\quad$ (16)

Small right PrdA: - PvdA: - PvdA: - PvdA: - PudA: - PvdA: 0

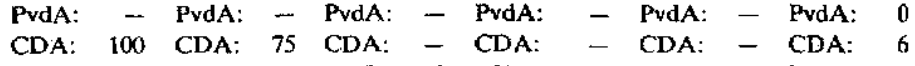
VVD: - VVD: - VVD: 50 VVD: - VVD: - VVD: 1 D66: - D66: - D66: - D66: 100 D66: - D66: 1 GL: - GL: 25 GL: - GL: - GL: - GL: 0 sr: - $\quad$ sr: $\quad-$ sr: 50 sr: $\quad$ s: sr: $\quad-$ sr: 90

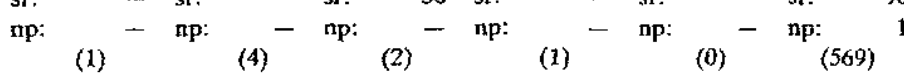


the children have parents with the same political party preference. Furthermore, these models are troublesome when analyzing the impact of heterogeneity effects per se. As Hope and Sobel stated, the main effects of father's and mother's political preference in these models contain some heterogeneity effects per se (Hope, 1971, 1975; Sobel, 1981).

In this study, we used multinominal logistic diagonal reference models. As Sorenson and Brownfield argued, diagonal reference models are more appropriate than classical techniques for the analysis of parental influence (Sorenson and Brownfield, 1991). The diagonal reference models as originally designed by Sobel are equipped to deal only with ordinal dependent variables (Sobel, 1981, 1985). In our study, we used a multinominal logistic version of these models. This version is equipped to deal with dependent variables with several nominal categories. Such an adaptation of the diagonal reference models is relevant because of the importance of treating political party preference as a nominal variable. Because the Dutch political party system can be characterized as multiparty system with a strong socioeconomic as well as a significant religious dimension, political parties cannot easily be placed on one dimension (Lijphart, 1975; Andeweg, 1982; Middendorp, 1991). In addition, our study treats not having a political preference as an important category of the dependent variable political preference.

The mechanism of the multinominal logistic diagonal reference models is best explained using Table 2. The upper left cell shows that children with politically homogeneous PvdA-parents have a $50 / 3$ odds of preferring the PvdA to having no political preference. This gives a log-odds of 2.81 $(=\log (50 / 3))$. The main diagonal cell, diagonally under it, shows that children with politically homogeneous CDA parents have a log-odds of - .69 $(=\log (2 / 4))$ of preferring the PvdA to having no political preference. Diagonal reference models assume that for children whose father prefers the PvdA and whose mother prefers the CDA, the log-odds of preferring the PvdA to having no political preference is a weighted mean of the above-mentioned log-odds for children with politically homogeneous PydA and homogeneous CDA parents. Assuming that the relative influence of fathers and mothers is equal for all children, according to the mechanism of the diagonal reference models, this log-odds can be calculated as: $\left(.5^{*} 2.81\right)+\left(.5^{*}-.69\right)=1.06 .^{5}$ Analogous calculations can be made for other children with other combinations of heterogeneous parents.

A general multinominal logistic diagonal reference, model can be represented as

$$
\pi_{i j p h}=\exp \left(\eta_{i j p}\right) / \Sigma \exp \left(\eta_{i j p}\right)
$$

\footnotetext{
${ }^{5}$ Note that the $\mu_{\text {iip }}$-parameters (of the main diagonal cells) and the weighting parameters are estimated simultaneously (see also Sobel (1981) and Footnote 7).
} 


$$
i j p=(\mathrm{R}) \mu_{i i p}+(1-\mathrm{R}) \mu_{j j p}+\mathrm{B}_{\mathrm{Lp}} * \text { covariate }_{\mathrm{L}} .
$$

In these formulas, $\pi_{i j p k}$ is the probability that child $k$ has party preference $p$, given the father's political party preference $i$ and the mother's political party preference $j$. The term $\eta_{i j p}$ stands for the log-odds that the same child $k$ prefers party preference $p$ to other party preferences. The parameters $\mu_{i i p}$ and $\mu_{j i p}$ indicate for child $k$, with various types of politically homogeneous parents, the log-odds of preferring party preference $p$ to other party preferences. The term $\mathrm{R}$ stands for the relative weight of the father's political party preference, and $(1-R)$ for the relative weight of the mother's political party preference. We include co-variates in the models representing socioeconomic class and religion, where $\mathbf{L}$ stands for the various co-variates and $\mathrm{B}_{\mathrm{Lp}}$ for the accompanying parameters. For each possible political party preference, $p$, with the exception of the reference category, a $B_{L}$ parameter was estimated. ${ }^{6}$ An important characteristic of the diagonal reference models is that these models are parsimonious in the use of parameters. For example, only a single parameter is needed to model the relative influence of the father's and mother's political party preference.

\section{TESTING THE HYPOTHESES}

\section{Model Selection}

To test the hypotheses, we fitted several diagonal reference models, each representing a single hypothesis or a combination of hypotheses. ${ }^{7}$

\footnotetext{
${ }^{5}$ The diagonal reference models have previously been applied in studying the effects of intergenerational social mobility (Nieuwbeerta and De Graaf, 1993; Weakliem, 1993) and partner's class position (De Graaf and Heath, 1992) on political preference. For more detailed information on the diagonal reference models, we refer the reader to Sobel $(1981,1985)$ and Hendrickx, De Graaf, Lammers, and Ultee (1994).

7 The estimation of the parameters of multinominal logistic diagonal reference models is straightforward (see Agresti, 1990, pp. 40-41, 316). We presume the political parties to be distinct and weighted independently, especially after conditioning on the explanatory variables (see McFadden, 1974). Consequently, given the observed data $\left\{n_{p}, p=1, \ldots, P\right\}$, and assuming multinominal sampling, the log likelihood function is

$$
\mathrm{L}=\Sigma \mathrm{n}_{p} \log \left(\pi_{i j p k}\right)
$$

To eliminate redundancies in the parameters, we treat $L$ as a function of the P-1 probabilities obtained by dropping $\pi_{p}$, since $\pi_{p}=1-\left(\pi_{1}+\ldots+\pi_{p-1}\right)$. A general multinominal logistic probability model can be given as

$$
\pi_{j i p k}=\exp \left(\eta_{i j p}\right) / \Sigma \exp \left(\eta_{i j p}\right)
$$

For diagonal reference models the $\eta_{\mathrm{ijp}}$ in this formula can be expressed as

$$
\eta_{i j p}=(\mathrm{R}) \mu_{i p \rho}+(1-\mathrm{R}) \mu_{j i p}+\mathrm{B}_{L p} * \text { covariate }_{\mathrm{L}}
$$

Since maximizing the log-likelihood is equivalent to minimizing the negative of the loglikelihood, we use the loss function in the CNLR procedure of SPSS-X to estimate the parameters of the specified models. Readers interested in more information on how to fit these models should write to the authors. 
To select the model that represented our data best, we compare the fit of one model with a less general one nested within that model. To detect whether the fits of models differ significantly, we use two measures: the traditional Likelihood-ratio test and the BIC (Bayesian Information Coefficient) ${ }^{8}$ Comparing both measures, the Likelihood-ratio test has the disadvantage that, when analyzing a large number of cases, differences between models easily turn out to be significant (Raferty, 1986). The BIC takes into account the number of cases in the analysis and is thus better equipped to make a selection between two models. A second advantage of this BIC is that it shows whether a model describes the data reasonably, i.e. if the BIC takes a negative value. When several models are compared, the model with the most negative BIC is the one to be preferred. The fit statistics of all the models are presented in Table 3.

Model A represents the equal-parental socialization hypothesis where the relative influence of fathers' and mothers' political party preferences are construed to be equal for all children. On the basis of the negative BIC we conclude that this model gives a reasonable presentation of the data. To test whether the equal-parental socialization hypothesis is to be rejected, we tested the other hypotheses.

The mother-dominated socialization hypothesis is reflected in Model B. This hypothesis assumes that the mother's political party preference has more influence on the political party preference of a child than the father's. To test our mother-dominated socialization hypothesis, we allow the relative influence of the father's and mother's political party preference to differ by adding a parameter $(\mathrm{M})$ to the relative weights in Model $\mathrm{A}$. Table 3 shows that, according to both the Likelihood-ratio test and the BIC, Model B does not result in a significant improvement in fit as compared to Model A. Consequently, the mother-dominated socialization hypothesis is to be rejected.

There are two gender-specific socialization hypotheses. The first states that a mother's political party preference has more influence on the political party preference of a daughter than a father's. The second states that a father's political party preference has more influence on the political party preference of a son than a mother's. Models C and D reflect these hypotheses for girls and boys separately while Model E reflects these hypotheses simultaneously. In these models we introduce an interaction between the weight parameter and the dummy variables girl and boy. This implies that the relative weight of father's and mother's political party preference is allowed to differ between boys and girls. If both our gender-specific socialization hypotheses are valid, the accompanying parameters $\left(\delta_{\text {girl }}\right.$ and $\left.\delta_{\text {toy }}\right)$ should be larger than zero. As the figures in Table 3 indicate, according to the Likelihood ratio test Models $\mathrm{C}, \mathrm{D}$, and $\mathrm{E}$ all

${ }^{8}$ The formula to calculate the $\mathrm{BIC}$ is $\mathrm{BIC}=\mathrm{L}^{2}-n d f * \log (\mathrm{N})$. 
TABLE 3

Multinomial Logistic Diagonal Reference Models for the Relative Effects of Fathers' and Mothers' Political Party Preference on Those of Their Children $(N=5148)$

\begin{tabular}{|c|c|c|c|c|c|}
\hline Model* & $d f_{\text {used }}$ & $L^{2}$ & & $\Delta \mathrm{L}$ & $\mathrm{BIC}$ \\
\hline A: Equal-parental socialization-hypothesis & 66 & 10640.32 & & & -32792.3 \\
\hline $\begin{array}{l}\text { B: Mother-dominated socialization- } \\
\text { hypothesis }\end{array}$ & 67 & 10640.28 & A-B & .04 & -32783.8 \\
\hline $\begin{array}{l}\text { C: Gender-specific socialization-hypothesis } \\
\text { for girls }\end{array}$ & 67 & 10631.98 & A-C & $8.34^{* *}$ & -32792.1 \\
\hline $\begin{array}{l}\text { D: Gender-specific socialization-hypothesis } \\
\text { for boys }\end{array}$ & 67 & 10630.20 & A-D & $10.12 * *$ & -32793.9 \\
\hline \multirow{3}{*}{$\begin{array}{l}\text { E: Gender-specific socialization-hypotheses } \\
\text { for girls and boys }\end{array}$} & 68 & 10622.38 & A-E & $17.94^{* *}$ & -32793.1 \\
\hline & & & $C-E$ & $9.60^{* *}$ & \\
\hline & & & D-E & $7.82^{* *}$ & \\
\hline F: Heterogeneity-hy & 67 & 10636.40 & A-F & $3.92^{*}$ & -32787.7 \\
\hline G: Magnitude of heterogeneity-hypothesis & 67 & 10636.40 & $A \cdot G$ & $3.92^{*}$ & -32787.7 \\
\hline
\end{tabular}

Note. The models were specified as follows:

$$
\pi_{\text {ijpk }}=\exp \left(\eta_{i p p}\right) / \Sigma \exp \left(\eta_{i p p}\right)
$$

Model:

$\mathrm{A}: \eta_{\mathrm{ijp}}=(.5) \mu_{\mathrm{ip}}+(.5) \mu_{i j p}+\mathrm{B}_{\mathrm{Li}} *$ covariate $_{\mathrm{L}}$

B: $\eta_{\mathrm{ipp}}=(.5-\mathrm{M}) \mu_{i \mathrm{p}}+(.5+\mathrm{M}) \mu_{\mathrm{ijp}}+\mathrm{B}_{\mathrm{Lp}} *$ covariate $_{\mathrm{L}}$

C: $\eta_{i j p}=\left(.5-\delta_{g i r l} *\right.$ girl $) \mu_{i p p}+\left(.5+\delta_{g r l} *\right.$ girl $) \mu_{i j p}+\mathbf{B}_{l, p} *$ covariate $_{l .}$

D: $\eta_{\text {iip }}=\left(.5+\delta_{\text {tay }} *\right.$ boy $) \mu_{\text {ip }}+\left(.5-\delta_{\text {hoy }} *\right.$ boy $) \mu_{\text {ifp }}+\mathrm{B}_{\mathrm{t}, p} *$ covariate $_{\mathrm{L}}$

$\mathrm{E}: \eta_{\mathrm{ijp}}=\left(.5-\delta_{\mathrm{girt}} *\right.$ girl $+\delta_{\text {hoy }} *$ boy $) \mu_{i \mathrm{ip}}+\left(.5+\delta_{\mathrm{g} i \mathrm{~s}} *\right.$ girl $-\delta_{\mathrm{tuy}} *$ boy $) \mu_{j i p}$ $+\mathbf{B}_{\mathrm{L}^{p}} *$ covariate $\mathrm{L}_{\mathrm{L}}$

F: $\eta_{\text {iip }}=(.5) \mu_{\text {iip }}+(.5) \mu_{i p p}+H *$ heterogeneity $+B_{L p} *$ covariate $_{L}$

$\mathrm{G}: \eta_{\mathrm{ijp}}=(.5) \mu_{\mathrm{ipp}}+(.5) \mu_{j j \mathrm{p}}+\mathrm{H} *$ magnitude of heterogeneity $+\mathrm{B}_{\mathrm{L}^{\prime}} *$ covariate $_{1}$

* Significant at the .05 level.

** Significant at the .01 level.

resulted in a significantly better fit than Model $\mathrm{A}$. Model $\mathrm{E}$ resulted in an significantly better fit than Models C and D. The BIC of Models C, $D$, and $E$ differ only slightly. There is, therefore, no reason for other conclusions. The estimated parameters $\delta_{\text {boy }}$ and $\delta_{\text {gir }}$ have, as expected, a positive value. These results corroborate the two gender-specific socialization hypotheses.

Both our heterogeneity hypotheses assume an independent effect of politically heterogeneous parents on the political party preference of their children. The heterogeneity hypothesis holds that children with politically heterogeneous parents are less apt to have a political preference than children with politically homogeneous parents. To test this hypothesis, we modified Model $\mathrm{F}$ by adding a dummy variable heterogeneity as covariate to Model A. According to the hypothesis, we should expect the accompanying parameter $\mathrm{H}$ to be smaller than zero. Table 3 shows that 
Model F, according to the Likelihood-ratio test, results in a marginally better fit than Model A. The BIC of Model F, however, is notably less negative than that of Model A. Furthermore, the estimated heterogeneity parameter $\mathrm{H}$ is, contrary to our expectations, larger than zero. Thus, this heterogeneity hypothesis has to be rejected.

According to the magnitude of heterogeneity hypothesis, the larger the magnitude of cross-pressures in a situation with heterogeneous parents, the more the chance that children will not show a political party preference. To test this hypothesis, model $G$ was developed. Model $G$ is largely the same as Model F, except that the variable amount of heterogeneity replaces the variable heterogeneity. The fit of Model G, according to both the Likelihood ratio test and the BIC, is coincidentally the same as that of Model F. This implies that the magnitude of heterogeneity hypothesis also has to be rejected. ${ }^{9}$

\section{Interpretation of the Parameters of the Best Model}

The model selection indicates that Model $\mathrm{E}$, representing the genderspecific socialization hypothesis for both boys and girls, gives the best data representation.

The upper part of Table 4 shows the estimated parameters of the relative weights of father's and mother's political party preference on the political party preference of their child, i.e. $\delta_{\text {girl }}$ and $\delta_{\text {boy }}$. The values impiy that the relative influence of the father's and mother's political party preference on that of their child is gender-specific. The relative effect of father's political party preference on that of a son $(.50+.07=.57)$ is greater than mother's $(.50-.07=.43)$, but mother's political party preference has more effect on the party preference of a daughter $(.50+.06=.56)$ than father's $(.50-.06=.44)$.

The estimated $\mu_{\mathrm{ip}}$-parameters of the model are presented in the middle part of Table 4. These parameters give the log-odds of preferring a specific political party to not preferring a specific political party for a non-religious child from a blue-collar background (the reference category) with politically homogeneous parents. From these estimated $\mu_{\text {ip }}$-parameters, we calculated the chance for preference for each political party for children with politically homogeneous parents. Chances are noted between brackets. The figures show that children with politically homogeneous parents have a high chance of having the same political preference as their parents.

Using both the parameters from the upper and middle part of Table 4 , the log-odds that children with politically heterogeneous parents will prefer a specific political party compared to not preferring a political party

"Both heterogeneity hypotheses have been also tested using models in which the dependent variable was dichotomised into no political party preference versus any political party preference. These tests, again, resulted in a rejection of both heterogeneity hypotheses. 
TABLE 4

Parameter Estimates of Multinomial Logistic Diagonal Reference Mode! E, Representing the Gender-Specific Socialization Hypotheses for Girls and Boys

\begin{tabular}{|c|c|c|c|c|c|c|c|c|c|c|c|c|c|c|c|}
\hline \multicolumn{16}{|c|}{ Gender-specific interaction effect } \\
\hline & & \multicolumn{14}{|c|}{ Log-odds of preferring a specific political party to no preference (probability to prefer a particular political party): } \\
\hline & & \multicolumn{2}{|c|}{ PrdA } & \multicolumn{2}{|c|}{$\mathrm{CDA}$} & \multicolumn{2}{|c|}{ VVD } & \multicolumn{2}{|c|}{ D66 } & \multicolumn{2}{|c|}{ Green left } & \multicolumn{2}{|c|}{ Small right } & \multicolumn{2}{|c|}{$\begin{array}{l}\text { No preference } \\
\text { (ref.) }\end{array}$} \\
\hline \multicolumn{16}{|l|}{ Politically homogeneous parents } \\
\hline PvdA & $\mu_{\text {PVdA.PvdA,P }}$ & 2.83 & $(60 \%)$ & -.32 & $(3 \%)$ & -.59 & $(2 \%)$ & 1.72 & $(20 \%)$ & 1.15 & $(11 \%)$ & -4.38 & $(0 \%)$ & 0 & $(4 \%)$ \\
\hline CDA & $\mu_{C D A, C D A, p}$ & -.71 & $(4 \%)$ & 1.88 & $(53 \%)$ & -.20 & $(7 \%)$ & .97 & $(21 \%)$ & -.18 & $(7 \%)$ & -5.78 & $(0 \%)$ & 0 & $(8 \%)$ \\
\hline VVD & $\mu_{\mathrm{VVD}, V \vee D, p}$ & -.78 & $(3 \%)$ & -.06 & $(6 \%)$ & 2.26 & $(64 \%)$ & .90 & $(16 \%)$ & -.72 & $(3 \%)$ & -8.17 & (0\%) & 0 & $(7 \%)$ \\
\hline D66 & $\mu_{D S 6, D S A, P}$ & -.14 & $(3 \%)$ & -.21 & $(3 \%)$ & .00 & $(4 \%)$ & 3.09 & $(78 \%)$ & .91 & $(9 \%)$ & -4.31 & $(0 \%)$ & 0 & $(4 \%)$ \\
\hline Green left & $\mu_{O L, G L, p}$ & .71 & $(3 \%)$ & -1.12 & $(0 \%)$ & -1.76 & $(0 \%)$ & 2.07 & $(13 \%)$ & 3.95 & $(82 \%)$ & -12.55 & $(0 \%)$ & 0 & $(2 \%)$ \\
\hline Small right & $\mu_{\text {sr.s.p.p }}$ & -1.43 & $(2 \%)$ & .36 & $(14 \%)$ & -1.41 & $(2 \%)$ & -.81 & $(4 \%)$ & -1.22 & $(3 \%)$ & 1.90 & $(65 \%)$ & 0 & $(10 \%)$ \\
\hline \multicolumn{16}{|l|}{ Covariates } \\
\hline $\begin{array}{l}\text { Religious, from non-manual } \\
\text { working class background }\end{array}$ & $\beta_{1 \mathrm{p}}$ & -.10 & & 1.32 & & .85 & & .56 & & -.03 & & 2.47 & & & \\
\hline $\begin{array}{l}\text { Religious, from manual } \\
\text { working class background }\end{array}$ & $\beta_{2 \mathrm{p}}$ & -.26 & & 1.10 & & -.10 & & .19 & & -.10 & & 2.40 & & & \\
\hline $\begin{array}{l}\text { Religious, from farmers } \\
\text { background }\end{array}$ & $\beta_{3 p}$ & .49 & & 1.73 & & 1.21 & & -.04 & & -.79 & & 3.62 & & & \\
\hline $\begin{array}{l}\text { Non-religious, from non-man- } \\
\text { ual working class } \\
\text { background }\end{array}$ & $\beta_{4 p}$ & -.18 & & .44 & & .63 & & .36 & & -.12 & & .63 & & & \\
\hline $\begin{array}{l}\text { Non-religious, from manual } \\
\text { working class background } \\
\text { (ref.) }\end{array}$ & - & 0 & & 0 & & 0 & & 0 & & 0 & & 0 & & & \\
\hline $\begin{array}{l}\text { Non-religious, from farmers } \\
\text { background }\end{array}$ & $\beta_{s p}$ & -.86 & & .87 & & 1.63 & & 1.21 & & .58 & & -1.90 & & & \\
\hline
\end{tabular}


can be calculated. Because the model selection indicated that intergenerational political socialization is gender-specific, we make a distinction between boys and girls. For example, the log-odds that a non-religious boy from a blue-collar background with a father who prefers the Labor Party (PvdA) and a mother who prefers the Christian Democratic Appeal (CDA) will prefer the PvdA to not preferring a political party is 1.31 (= $(.50+.07) * 2.83+(.50-.07) *-.71)$. For girls in the same situation the log-odds is .85 . There is a $28 \%$ chance that boys will prefer the PvdA. For girls the chance is $23 \%$.

The lower part of Table 4 gives the effect of socioeconomic class and religion. As mentioned above, non-religious children from a blue-collar background serve as the reference category. The values indicate the difference in the log-odds between a child who prefers a specific party to not preferring any party, in the reference category, and a child with the same preference who belongs to a different social class. For example, the log-odds that a religious boy with a manual working class background will prefer the PvdA rather than no political party is $1.05(=1.31-.26)$, for the same category girl, $.59(=.85-.26)$. Using similar computations, the log-odds that a specific party is preferred rather than no party can be calculated.

\section{CONCLUSIONS AND DISCUSSION}

The main purpose of this study has been to examine the intergenerational transmission of political party preference. Hypotheses were formulated using earlier political socialization studies concerning the influence of a father's and a mother's political party preference on that of their child. These hypotheses were tested by analyzing data from a survey held among high school students in The Netherlands in 1991.

The mother-dominated socialization hypothesis states that a mother's political party preference has more influence on the political party preference of the child than father's. However, the outcomes of our empirical analysis imply that, in general, the relative influence of the father's and mother's political party preference did not differ. The results of our analysis confirm the gender-specific socialization hypotheses. The analysis shows that mother's political party preference has more impact on daughter's political party preference than does father's. Father's political party preference has more impact on son's political party preference than mother's. This has major theoretical implications. It implies that the traditional idea of the father's political role as being dominant has to be rejected. In addition, the idea that the mother is the dominant political socialization agent because she spends more time with her children has to be revised. This implies that simple theories about the roles that fathers and mothers play in the political socialization of their children will not suffice. Future research should focus on the specific roles of fathers and mothers. It could, for example, be useful to examine whether sons and daughters 
discuss or argue politics more frequently with their father or with their mother. Additionally, it is worthwhile to investigate whether gender-specific socialization processes occur with respect to political orientations other than party preference.

The heterogeneity hypothesis has to be rejected. This hypothesis states that children with politically heterogeneous parents are less likely to have a political party preference than children with politically homogeneous parents. The result contradicts the cross-pressure theory suggested by Lazarsfeld et al. (1948): Voters exposed to a cross-pressure situation are confused and consequently have less of a chance of having a political party preference than voters who are not exposed to a cross-pressure situation. An explanation for our findings may be that children with heterogeneous parents do not feel they are in a cross-pressure situation. It is possible that parents do not pressure their children into having the same political preference.

The findings of this study show a fairly strong parental political socialization in the Netherlands. Politically homogeneous parents are especially successful in transmitting their political preference to their children. This seems to contradict earlier findings which show that in the Netherlands a fairly low rate of intergenerational transmission of party preference exists. An explanation for these earlier findings might be the high percentage of politically heterogeneous parents in The Netherlands due to the existence of many political parties. These heterogeneous parents are apparently relatively less successiul in transmitting their party preference. As a result, intergenerational transmission of political party preference in the Netherlands seems less than in other countries. In future international comparisons, it is advisable to focus separately on the transmission of party preferences to children with politically homogeneous parents and to children with politically heterogeneous parents.

Due to the limitations of our data, we have had to assume that the parent's political party preference as perceived by their children was the same as the parent's actual political party preference. Furthermore, we were unable to analyze mutual influences of fathers and mothers and of children and their parents. Future political socialization research should focus on large scale surveys in which not only the children but the parents as well are followed separately over a longer period of time. If these surveys are held in different countries, it would be possible not only to describe cross-national differences in political socialization processes but also to test for possible explanations for these differences.

\section{REFERENCES}

Acock, A. C., and Bengtson, V. L. (1980), "Socialization and attribution processes: actual versus perceived similarity among parents and youth," Journal of Marriage and the Family 42, 501-515.

Agresti, A. (1990), Categorical Data Analysis, Wiley, New York. 
Andeweg, R. (1982), Dutch Voters Adrift: On Explanations of Electoral Change 19631977, Leiden.

Asher, H. (1980), Presidential Elections: American Politics: Voters, Candidates, and Campaigns since 1952 (revised edition), Dorsey Press, Homewood.

Bengtson, V. L., and Kuypers, J. A. (1971), "Generational difference and the developmental stake," Aging and Human Development 2, 249-260.

Butler, D., and Stokes, D. (1969), Political Change in Britain, MacMillan, London.

Campbell, A., Converse, P. E., Miller, W. E., and Stokes, D. E. (1960), The American Voter, John Wiley \& Sons, New York.

Converse, P. E., and Pierce, R. (1986), Political Representation in France, Belknap Press of Harvard Univ. Press, Cambridge.

De Graaf, N. D., and Heath, A. (1992), "Husbands' and wives' voting behavior in Britain: class-dependent mutual influence of spouses," Acta Sociologica 35, 311-322.

De Hart, J. J. M. (1990), Levensbeschouwelijke en Politieke Praktijken van Nederlandse Middelbare Scholieren, Kok, Kampen.

Flanagan, S. C. (199i). "Mechanisms of social network influence in Japanese voting behavior," In The Japanese Voter (S. C. Flanagan, S. Kohei, I. Miyake, B. M. Richardson, and J. Watanuki, Eds.), pp. 143-197, Yale Univ. Press, New Haven.

Flanagan, S. C., Kohei, S., Miyake, I., Richardson, B. M., and Watanuki J. (1991). the Japanese Voter, Yale Univ. Press, New Haven.

Hagendoorn, L., and Janssen, J. (1983), Rechtsomkeer: Rechtsextreme Opvattingen bij Leerlingen van Middelbare Scholen, Ambo, Baarn.

Hendrickx, J., De Graaf, N. D., Lammers, J., and Ultee, W. (1993), "Models for status inconsistency and mobility: A comparison of the approaches by Hope and Sobel with the mainstream square additive model," Quality and Quantity 27, 335-352.

Himmelweit, H. T., Humphreys, P., Jaeger, M., and Katz, M. (1981), How Voters Decide: A Longitudinal Study of Political Attitudes and Voting Extending over Fifteen Years, Academic Press, London.

Hope, K. (1971), "Social mobility and fertility," American Sociological Review 36, 1019 1032.

Hope, K. (1975), "Models of status inconsistency and social mobility effects," American Sociological Review 40, 322-343.

Hyman, H. H. (1959), Political Socialization: A Study in the Psychology of Political Behavior, Free Press, Glencoe.

Janssen, J., and Voestermans, P. (1984), Studenten in Beweging, Ambo, Baarn.

Jennings, M. K. (1984), "The intergenerational transfer of political ideologies in eight Western Nations," European Journal of Political Research 12, 261-276.

Jennings, M. K., and Niemi, R. G. (1971), "The division of political labor between mothers and fathers," American Political Science Review 65, 69-82.

Jennings, M. K., and Niemi, R. G. (1974), The Political Character of Adolescence: The Influence of Families and Schools, Princeton Univ. Press, Princeton.

Jennings, M. K., Allerbeck, K., and Rosenmayr, L. (1979), "Generations and family," in Political Action: Mass Participation in Five Western Democracies (S. H. Barnes, M. Kaase et al., Eds.), Sage, Beverly Hills.

Jennings, M. K., and Niemi, R. G. (1981), Generations and Politics: A Panel Study of Young Adults and Their Parents, Princeton Univ. Press, Princeton.

Langton, K. P., and Jennings, M. K. (1969), "Mothers versus fathers in the formation of political orientations," in Political Socialization (K. P. Langton, Ed.), pp. 52-83, Oxford Univ. Press, New York.

Lazarsfeld, P. F., Berelson, B., and Gaudet, H. (1948), The People's Choice: How the Voter Makes Up His Mind in Presidential Campaigns, Colombia Univ. Press, New York. 
Lijphart, A. (1975), The Politics of Accommodation: Pluralism and Democracy in The Netherlands (second revised edition), University of California Press, Berkely.

Maccoby, E. E., and Jacklin, C. N. (1974), The Psychology of Sex Differences, Stanford Univ. Press, Stanford.

McFadden, D. (1974), "Conditional logit analysis in qualitative choice behavior," in Frontiers in Econometrics (P. Zarembka, Ed.), pp. 105-142, Academic Press, New York.

Middendorp, C. P. (1991), Ideology in Dutch Politics: The Democratic System Reconsidered 1970-1985, Van Gorcum, Assen.

Niemi, R. G. (1973), "Collecting information about the family: A problem in survey methodology," in Socialization to Politics: A Reader (J. Dennis, Ed.), pp. 464-490, Wiley, New York.

Niemi, R. G. (1974), How Family Members Perceive Each Other: Political and Social Attitudes in Two Generations, Yale Univ. Press, New Haven.

Niemi, R. G., Ross, R. D., and Alexander, J. (1978), "The similarity of political values of parentsen college-age youth," Public Opinion Quarterly 42, 503-520.

Niemi, R. G., Newman, D., and Weimer, D. L. (1982), "Reassessing the political influence of parents on children," Micropolitics 2, 203-217.

Nieuwbeerta, P., and De Graaf, N. D. (1993), "Intergenerational class mobility and political preferences between 1970 and 1986 in The Netherlands," Netherlands' Journal of Social Sciences 29, 28-45.

Nieuwbeerta, P., and De Graaf, N. D. (1995), "Sociale klasse, mobiliteit, trouwpatronen en politieke voorkeur," in Ongelijkheid in Nederland (J. Dronkers and W. Ultee, Eds.), pp. 182-201, Van Gorcum: Assen.

Percheron, A., and Jennings, M. K. (1981), "Political continuities in French families: A new perspective on an old controversy," Comparative Politics 13, 421-436.

Raferty, A. E. (1986), "Choosing modeis for cross-classifications," American Sociological Review 51, 145-146.

SCP (1994), Rapportage Jeugd 1994, Sociaai en Cultureel Pianbureau, Rijswijk.

Sobel, M. E. (1981), "Diagonal mobility models: A substantively motivated class of designs for the analysis of mobility effects," American Sociological Review 46, 893-906.

Sobel, M. E. (1985), "Social mobility and fertility revisited: some new models for the analysis of the mobility effects hypothesis," American Sociological Review 50,699712.

Sorenson, A. M., and Brownfield, D. (1991), "The measurement of parental influence, assessing the relative effects of father and mother," Sociological Methods and Research 19, 511-535.

Sperlich, P. (1971), Confiict and Harmony in Human Affairs: A Study of Cross Pressures and Political Behavior, Rand McNally \& Company, Chicago.

Thomassen, J. (1976), "Party identification as a cross-national concept: its meaning for the Netherlands," in Party Identification and Beyond: Representations of Voting and Party Competition (I. Budge, I. Crewe, and D. Farlie, Eds.), pp. 63-79, Wiley, London.

Van der Eijk, C., and Niemöller, K. (1992), "Netherlands," in Electoral Change: Responses to Evolving Social and Attitudinal Structures in Western Countries (M. Franklin, T. Mackie, and H. Valen, Eds.), pp. 255-283, Cambridge Univ. Press, Cambridge.

Weakliem, D. (1992), "Does social mobility affect political behaviour?" European Sociological Review 8, 153-165.

Westholm, A., and Niemi, R. G. (1992), "Political institutions and political socialization: a cross-national study," Comparative Politics 24, 25-41.

Wittebrood, K. (1993a). "Intergenerationele overdracht van politieke-partijvoorkeur in Nederland," Sociologische Gids 40, 126-139.

Wittebrood, K. (1993b). "De verwaarlozing van 'weet niet' antwoorden; een reactie op $\mathrm{H}$. van Goor," Sociologische Gids, 40, 440-442. 